\title{
INJIL SEBAGAI KABAR TENTANG KEMBALINYA KEMULIAAN TUHAN KE DALAM SEGENAP CIPTAAN
}

\author{
Jadi Sampurna Lima \\ Sekolah Tinggi Teologia Reformed Injili Internasional \\ Reformed Millennium Center Indonesia, Jl. Industri Blok B14 Kav. 1, Jakarta Pusat, 10720 \\ Email: yadislima@gmail.com
}

\begin{abstract}
This article surveys various understanding on what the Gospel is: as 'how to get into heaven', a declaration about forgiveness of 'personal sins', an invitation for a social-political revolution, and a good news about the fulfillment of God's promise to Israel. The author argues for a theological and hermeneutical option to understand the gospel in a wider meta-narrative of creation, fall, and redemption. This option use a motif of 'the return of God's glory into the whole creation' as a paradigm to understand the gospel. This article tries to show how polarization between 'the gospel of personal salvation' and 'the social gospel' can be overcome by understanding the gospel as a declaration of the 'return of God's glory into creation'.
\end{abstract}

Key Words: Gospel, Kingdom, Creation, Sin, Salvation, Jesus, Culture, Politics

\begin{abstract}
ABSTRAK: Artikel ini membahas aneka ragam pemahaman tentang apa itu Injil: sebagai 'cara untuk masuk surga', berita tentang pengampunan 'dosa-dosa pribadi', suatu undangan bagi revolusi sosialpolitik, sampai suatu kabar tentang penggenapan janji TUHAN kepada umat-Nya. Dalam artikel ini akan dipertimbangkan sebuah opsi teologis dan tafsir untuk memahami Injil dalam konteks meta-naratif yang lebih luas, yakni didalam penciptaan, kejatuhan, dan penebusan. Opsi teologis ini memakai motif 'kembalinya kemuliaan Allah ke dalam seluruh ciptaan' sebagai paradigma untuk memahami Injil. Artikel ini menunjukkan bagaimana polarisasi antara 'Injil keselamatan pribadi' dan 'Injil sosial' dapat diatasi dengan memahami injil sebagai deklarasi tentang 'kembalinya kemuliaan Allah ke dalam segenap ciptaan'.
\end{abstract}

Kata-kata Kunci: Injil, Kerajaan, Penciptaan, Dosa, Keselamatan, Yesus, Kebudayaan, Politik

\section{PENDAHULUAN}

Di antara lebih dari lima puluh responden dalam kelas katekisasi yang diwawancarai sehubungan dengan pertanyaan-pertanyaan seputar: "Apakah Injil menurut anda?"dan "Apakah yang baik dari Kabar Baik itu?" hampir seluruh peserta secara spontan menjawab pertanyaan "apakah Kabar Baik di dalam Injil itu" dengan jawaban "Kabar Baiknya adalah Yesus telah mati menggantikan hukuman yang seharusnya aku tanggung akibat dosaku sehingga aku sekarang telah diselamatkan."Biasanya penulis akan mengatakan, "Itu jawaban yang bagus, Alkitab memang mengatakannya, tetapi apakah itu sudah keseluruhannya? Adakah hal lain yang anda baca di Alkitab sehubungan dengan Injil Yesus Kristus?" Biasanya para responden akan menjawab, "Kebangkitan Yesus membuktikan bahwa Ia berhak dan memang mampu menanggung dosa saya sebab itu berarti Yesus memang adalah Allah - sebab semua manusia yang sudah mati tidak bangkit." Lalu penulis akan mengatakan, "Apakah masih ada lagi? Apakah hanya dua poin itu?" Di sini biasanya percakapan mulai macet. Mereka akan menanggapi lagi, "Apakah yang anda maksud? Bukankah Yesus yang telah mati dan bangkit menggantikan posisiku sebagai terhukum di hadapan Tuhan yang murka adalah Kabar Baiknya?" Para responden ini adalah para peserta kelas katekisasi di GRII Kemayoran, Jakarta pada periode tahun 2014-2016 yang dipilih secara acak oleh penulis untuk menjawab pertanyaan ini dalam interview yang dilakukan di luar kelas secara sendiri-sendiri. Penulis tidak secara langsung mewawancarai warga gereja-gereja lain, tetapi menganggap hasilnya akan tidak terlalu berbeda. 
Di sini terlihat bahwa Injil seringkali dipahami sebagai 'obat bagi rasa bersalah dan rasa takut akan hukuman'. Ini adalah apa yang disebut oleh Willard (1997) sebagai 'Injil manajemen dosa'. Pemahaman semacam ini tidak secara langsung relevan dengan kehidupan sosial atau bahkan proses pengudusan pribadi. Dalam peng-hayatan Injil seperti ini, tidak ada hubungan langsung antara tindakan Tuhan menghapus ketakutan orang akan hukuman dengan apa yang sedang dikerjakan atau apa yang ingin Tuhan kerjakan di dalam realitas sosial, misalnya mengenai kemiskinan, ketidakadilan sistemik, korupsi, atau krisis ekologis. Bahkan, pemahaman begini juga kurang jelas kaitannya dengan proses 'pengudusan pribadi' - misalnya, apakah kaitannya pengampunan itu dengan kehidupan yang masih diwarnai dengan kecongkakan, keserakahan, irihati, hawa nafsu,dan segala kejahatan lainnya? Dengan kata lain, Injil dalam pemahaman semacam ini hanya beroperasi dalam domain 'internal gereja' sebagai bagian daripada 'ritual' belaka dan tidak sampai kepada 'etika sosial' yang berfungsi secara langsung sebagai 'sistem operasi' di dalam realitas sehari-hari. Tentu saja ada juga potret yang berbeda di dalam kehadiran gereja di Indonesia sehubungan dengan problema-problema sosial yang ada. Misalnya dalam catatan Singgih mengenai sikap gereja Katolik yang berpihak kepada kaum miskin yang hendak dikorbankan oleh pemerintah Orde Baru pada era 1980an atas nama kemajuan (Singgih, 2012, p. 318). Tetapi secara umum kritik dan tindakan yang ditujukan untuk menjawab masalah-masalah ketidakadilan di dalam struktur produksi dan sosial seperti ini adalah pengecualian. Sebagian besar gereja-gereja di Indonesia dapat dikatakan gagal untuk berdampak secara signifikan dalam menyuarakan kritik atau alternatif terhadap hal-hal buruk yang terus berlangsung di dalam masyarakat Indonesia, misalnya soal praktik korupsi atau nepotisme (Singgih, 2012, p. 318). Praktik kekristenan dan relevansi Injil bagi sebagian orang-orang Kristen semacam ini cenderung sebatas 'kehidupan setelah kematian', 'relasi pribadi dengan
Tuhan', atau urusan-urusan privat lainya - sedangkan urusan keadilan sosial dan ketimpangan dan penindasan dalam struktur sosial dipandang sebagai sesuatu yang 'tidak terhindarkan di dalam dunia berdosa.' sehingga seolah-olah Injil tidak bersuara apaapa secara langsung. Dalam penghayatan Injil semacam ini kemiskinan dianggap sebagai sesuatu keadaan yang 'kebetulan' dan didukung dengan perkataan di dalam Injil bahwa 'orang miskin akan selalu ada padamu' (Ngabalin, 2017, p. 139-140). Jika dilihat bagaimana Injil Yesus Kristus muncul dalam sejarah dan apa yang telah terjadi di antara mereka yang bersentuhan dengan Injil itu gambarannya tidaklah seperti ini. Banyak sejarawan telah mencatat bagaimana Injil mengenai datangnya pemerintahan YHWH di tengah umat-Nya yang dikabarkan oleh Yesus Nazaret itu telah mengubah wajah masyarat Romawi secara perlahan namun signifikan (Brown, 1997).

Injil memiliki posisi strategis di dalam kekristenan. Dua ribu tahun lampau orang-orang Kristen memulai suatu gerakan agama yang berbeda dari Yudaisme, agama-agama mistis, dan sekte-sekte filsafat lainnya yang beraneka ragam di dalam Kekaisaran Romawi karena mereka 'percaya kepada Injil'. Apakah yang disebut 'percaya kepada Injil' itu? Apakah 'Injil' itu? Jika Injil dilihat sebagai suatu 'kabar' yang 'baik' maka pertanyaannya: apakah Kabarnya? Apakah yang 'baik' dalam Kabar Baik itu? Apakah hubungannya Kabar Baik itu dengan apa yang Tuhan kerjakan di dalam Yesus dari Nazareth dan apakah kaitannya dengan manusia, baik di masa yang lampau, di Palestina pada abad pertama, maupun kaitannya dengan orang-orang di Indonesia dan di segala penjuru dunia pada masa kini. Adakah yang terlupakan dalam pemahaman tentang Injil Yesus Kristus sehingga seringkali Injil Yesus Kristus sulit dicari relevansinya dengan kehidupan di masa kini?

Penelitian tentang makna Injil yang 'sepenuhnya' atau 'sebenarnya' tentu saja sangat penting. Mengingat ini adalah salah satu 'esensi', 'titik pusat', atau 'ciri khas' dari Kekristenan - tetapi ke- 
giatan ini bukan tanpa risiko, sebab 'titik pusat' dari suatu gerakan sosial seringkali juga adalah 'titik tengkar' yang panas. Risiko itu akan penulis tempuh demi tidak meluputkan suatu kabar yang sedemikian baik, yang melaluinya Tuhan hendak memberkati segenap ciptaan - atau lebih baik lagi: melaluinya $\mathrm{Tu}$ han hendak memulihkan kemuliaan-Nya di dalam segenap ciptaan.

Beberapa penelitian telah dikerjakan untuk memperjelas dan mempertengkarkan apakah 'isi' dari Kabar Baik yang umumnya disebut sebagai Injil itu dan bagaimanakah sebaiknya Injil dipahami serta dihayati di dalam kehidupan di masa kini (Gilbert, 2010; McKnight, 2016). Penelitian-penelitian yang ada dikerjakan dengan menggali ulang cara-cara membaca teks sehubungan dengan Injil dan juga perkembangan pemahaman tentang Injil di dalam sejarah pemikirannya dengan melihat opsi-opsi filosofis dan teologisnya. Apa yang menurut hemat penulis cukup baru dalam tulisan ini adalah bahwa penulis berusaha untuk mengaitkan pemahaman kabar baik Kekristenan sebagai 'Injil pengampunan dosa lewat penebusan' dengan konsep lain yang juga terdapat di dalam Kekristenan, yakni: 'kemuliaan Allah' dan janji tentang 'pemulihan segenap ciptaan'. Penekanan yang kuat akan motif 'kemuliaan Allah' sebagai tujuan akhir dari segala sesuatu bukanlah hal yang baru. Katekismus Singkat Westminster menjawab pertanyaan 'apakah tujuan akhir dari keberadaan manusia?' dengan 'untuk memuliakan dan menikmati Allah selamanya' (T/J: \#1). Banyak penulis dari kalangan injili, seperti misalnya John Piper dan Christopher Wright, juga menekankan hal yang serupa. Piper(2010, p. 35-46), di dalam buku Let the Nations be Glad menekankan kemuliaan Allah dan penyembahan kepada Allah yang mulia sebagai tujuan akhir dari misi, dan bukan sebaliknya. Tujuan akhir dari misi dan pengabaran Injil bukanlah misi dan pengabaran Injil itu sendiri, melainkan agar Allah ada penyembahan kepada Allah yang sejati di dalam segenap kemuliaan-Nya.Wright di dalam studi tentang arti dari konsep 'keselamatan' di dalam
Alkitab pada akhirnya mendefinisikan keselamatan sebagai kembalinya berkat-berkat TUHAN di dalam segenap ciptaan. Wright mengatakan bahwa, "Pada akhirnya, keselamatan yang dari Tuhan adalah restorasi dari berkat-berkat ilahi ke dalam ciptaan dan kemanusiaan. Keselamatan bukan berarti menyelamatkan manusia keluar dari ciptaan, menuju suatu alam yang berbeda, melainkan membawa berkatberkat ilahi kembali ke dalam ciptaan, melalui kekuatan Allah yang menebus dan mengubahkan. Maka, keselamatan adalah misi Allah untuk memberkati dan menebus, merestorasi segenap ciptaan kepada keadaan yang telah hilang karena dosa dan pemberontakan manusia" (Wright, 2007, p. 69). Pemahaman Injil sebagai kabar tentang pemulihan kemuliaan Allah di dalam segenap aspek ciptaan ini menurut penulis dapat mengakomodasi penghayatan Injil sebagai 'pengampunan', 'keselamatan jiwa', 'pertobatan', 'pengudusan', dan juga 'tugas sosialpolitis-ekologis gereja' sebagai satu kesatuan holistik.

Tulisan ini akan mempersoalkan bagaimana Injil dapat dipahami dan dihayati dengan lebih utuh dan baik dengan mengalihkan titik pusatnya dari 'keluputan dari hukuman Tuhan' kepada 'pemulihan kemuliaan Tuhan'. Tentu saja ini bukan berarti penulis hendak mengatakan bahwa Injil tidak menjanjikan pengampunan dosa ataupun pertobatan. Yang hendak ditekankan di sini adalah bahwa Injil jangan dipahami sebatas sebagai jawaban atas permasalahan manusia belaka, tetapi sebagai penggenapan dari kehendak dan janji Alah - yang tentu saja mencakup juga manusia dan segenap ciptaan yang dikasihi-Nya itu. Demikian penulis berharap polarisasi antara kutub 'Injil keselamatan jiwa pribadi' dengan 'Injil perubaan struktur sosial' atau polarisasi antara 'mandat Injil' dengan 'mandat budaya' dapat diperlunak melalui pemakaian 'hal ketiga' yang menurut penulis dapat diterima oleh kalangan yang lebih luas, yakni: kemuliaan Allah, kedaulatan Allah, dan kesejahteraan segenap ciptaan sebagai perwujudan kehendak Allah. 


\section{METODE}

Berangkat dari pengamatan sederhana tentang kurang tuntasnya pemahaman warga gereja atas Injil dan apa yang dimaksudkan dengan keselamatan, penulis akan memeriksa persoalan ini dari caracara yang kerap dipakai untuk memahami apa itu Injil dan keselamatan di dalam Alkitab. Persoalan yang ingin dicari pemecahannya dalam tulisan ini adalah bagaimana mengatasi kurangnya pemahaman akan panggilan sosial-politis-ekologis dari umat percaya, yang menurut penulis, disebabkan oleh pemahaman akan Injil yang tidak utuh. Ada polarisasi antara pemahaman dan penghayatan Injil Yesus Kristus sebagai 'berkenaan langsung dengan masalahmasalah sosial-politik' dengan penghayatan yang lebih menekankan 'kesalehan pribadi' (seperti tercermin di dalam observasi yang dituliskan pada bagian pengantar artikel ini). Dalam tulisan ini penulis akan menyelidiki penyebabnya dari cara-cara memahami Injil yang tidak utuh tersebut dengan menilik proses teologis-hermeneutisnya. Hal ini penulis lakukan untuk menunjukkan bahwa ada yang hilang di dalam pemahaman populer orang-orang Kristen tentang Injil, yakni aspek politis dari deklarasi Yesus Nazaret tentang datangnya 'kerajaan Allah' - yakni penggenapan dari 'pengharapan Israel'. Aspek yang terlupakan dari Injil inilah yang menurut penulis menyebabkan polarisasi antara orang-orang Kristen yang menghayati imannya sebagai 'keselamatan pribadi' yang tidak ada kaitannya secara langsung dengan masalah-masalah sosial, politik, maupun ekologis; dan di sisi lain orang-orang Kristen yang menyadari betul bahwa dosa-dosa struktural seperti praktik-praktik bisnis yang berkelindan dengan praktik-praktik politik dan birokrasi yang korup adalah sama buruknya - kalau bukan jauh lebih berdosa daripada judi, pornografi, dan zinah. Hipotesa yang hendak diuji oleh penulis adalah bahwa dengan memahami Injil sebagai kabar baik bukan hanya soal pengampunan dosa dan keluputan dari hukuman, tetapi terutama sebagai kembalinya kemuliaan Allah di dalam segenap ciptaan, akan memungkinkan relevansi Injil dengan masalah-masalah sosial-politik dan masalah-masalah kesalehan pribadi dapat terlihat dengan jernih.

\section{PEMBAHASAN}

\section{Fokus dari Injil}

Bagian ini akan membahas implikasi negatif dari salah satu cara paling populer untuk melihat kabar baik di dalam Injil, yakni sebagai kabar baik tentang dilepaskannya si pendosa dari hukuman atas kesalahannya. Menurut hemat penulis, cara pandang ini hanya menekankan salah satu aspek dari Injil, sedangkan masih ada aspek-aspek lain dari Injil itu yang terluputkan pada cara pandang ini, yakni aspek keadilan dan kebaikan di dalam keseluruhan keadaannya. Misalkan ada seorang penjahat perang yang setelah diadili tidak mendapatkan hukuman sama sekali karena 'alasan kemurahan hati dan belas kasihan' dari si hakim, tentu saja orang dapat mengatakan bahwa keputusan pak hakim itu tidak adil. Keputusan itu mungkin dirasa baik oleh si terdakwa tetapi tidak akan terdengar sebagai kabar baik bagi para penyintas kejahatan perang yang dilakukan si terdakwa yang telah terbukti bersalah namun tidak dihukum dengan sewajarnya tersebut. Keputusan si hakim untuk sekedar melepaskan si penjahat dari hukuman juga tidak menyebabkan si penjahat ataupun situasi tersebut secara keseluruhan menjadi lebih baik.Untuk mengambil contoh dari dalam Perjanjian Baru, apakah pembebasan Yesus bar-Abbas oleh Pontius Pilatus adalah kabar baik bagi semua pihak? Pembebasan Bar-Abbas itu tentu bukanlah kabar baik bagi Maria ibu Yesus Nazaret, dan juga bagi Simon, Yohanes, dan para pengikut Yesus yang lain pada saat hal itu terjadi. Pembebasan Bar-Abbas itu berarti Yesus Nazaret yang bagi mereka tidak bersalah akan disalibkan secara tidak adil. Lalu mengapakah hal demikian dipahami, disebut, dan dihayati sebagai 'kabar baik' oleh orang-orang Kristen hari ini? 


\section{Dua Fokus Injil: Keselamatan Jiwaku ataukah Kemuliaan Tuhan?}

Pandangan yang mengatakan bahwa Kabar Baik di dalam Kekristenan adalah bahwa orang percaya telah diselamatkan dari hukuman Tuhan, berfokus pada masalah-masalah si pendosa tersebut. Persoalannya adalah si pendosa itu berada di dalam status terhukum, sehingga memiliki prospek masa depan yang suram. Ada beberapa keberatan terhadap titik berangkat ini. Pertama, apakah 'keselamatan jiwa' manusia adalah yang terpenting dari segala yang ada? Tidakkah ada sesuatu yang lain, yang lebih penting daripada 'keselamatan manusia' -semisal: kehendak Tuhan dan kemuliaan-Nya? Kedua, apakah masalah paling serius dari manusia adalah bahwa ia ada di bawah hukuman Allah? Tidakkah fakta bahwa ia ada di bawah hukuman itu disebabkan oleh sesuatu yang lebih serius, yakni ia telah memberontak terhadap kedaulatan pemerintahan Tuhan sehingga ia patut dihukum? Yang manakah problema yang lebih serius: manusia berada di bawah vonis mati Tuhan, ataukah telah terjadi makar di dalam kerajaan Allah? Manakah yang lebih menyedihkan, apakah manusia dihukum secara adil oleh Tuhan yang adil, ataukah bahwa manusia yang seharusnya mulia, karena diciptakan seturut dengan gambar dan rupa Allah, sekarang telah merosot menjadi begitu rusak, sehingga pancaran kemuliaan Allah di dalam dunia menjadi pudar?

Perbedaan antara 'hukuman Tuhan' dan 'keadaan yang menyebabkan hukuman tersebut' mungkin terlihat tipis, tetapi sesungguhnya ini tidak dapat begitu saja diabaikan. Masalah paling serius dalam relasi dengan Tuhan bukan ada pada 'hukuman' yang Tuhan timpakan, atau mungkin juga pada 'kemarahan' Tuhan akan dosa, melainkan pada manusia itu sendiri. Manusia telah melanggar perjanjian ciptaan dengan Sang Pencipta. Dengan kata lain, tidak ada yang salah di pihak Tuhan. Yang salah adalah manusia, sehingga tidak heran solusinya seharusnya juga bersangkut-paut dengan diri manusia itu. Diri manusia lah yang seharusnya berubah, bukan diri Tu- han, karena tidak ada hal yang salah yang harus diubah pada diri Tuhan. Untuk melihat bagaimanakah pandangan tentang permasalahan kejatuhan yang pusatnya sekarang bergeser dari pudarnya kemuliaan Allah di dalam ciptaan menjadi problema ketakutan eksistensial manusia akan hukuman Allah penulis akan menilik sejarah perkembangan konsep ini.

\section{Penghayatan Injil dalam Abad Pertengahan dan Reformasi Protestan}

Takut akan hukuman dosa sudah dialami manusia dari waktu yang tidak dapat diperkirakan. Dalam kisah Kejatuhan, si Adam dan Hawa bersembunyi di antara semak belukar ketika mendengar bunyi langkah Tuhan karena mereka takut dan malu (Kej. 3:10). Barangkali kegagalan untuk meratapi berkurangnya kemuliaan Allah dalam ciptaan, dan lebih berfokus kepada ketakutan akan hukuman atau rasa frustrasi akan kehidupan yang kosong, adalah bagian dari efek dosa itu sendiri. Penulis berpendapat bahwa pergeseran locus keprihatinan ini ada hubungannya dengan pergeseran titik fokus dari extra se menjadi in curvatus in se sebagaimana dikatakan para teolog Augustinian tentang efek dosa yang membengkokkan arah perhatian manusia kepada dirinya sendiri (Littlejohn, 2017). Di dalam sejarah Gereja Eropa Barat di Abad Pertengahan, ada gambaran Allah yang menakutkan, yakni gambaran Allah sebagai Raja atau Hakim yang Adil, yang murka terhadap dosa manusia. Dapat dikatakan inilah yang disebut oleh tokoh Reformasi Protestan, Martin Luther dengan Anfechtung - siksaan batin karena ia tak dapat memenuhi tuntutan Allah, yang adalah Hakim yang adil itu. Bagi orang di Abad Pertengahan, agar manusia dapat mengalami perkenan Allah dan lolos dari murka-Nya manusia haruslah memenuhi tuntutan-tuntutan hukum-Nya yang sempurna. Manusia gagal memenuhi tuntutan-tuntutan itu. Tidak heran, bagi Luther Allah adalah Hakim yang murka. Anthony Lane menulis demikian tentang Luther: 
Kepadanya diajarkan bahwa supaya Allah berkenan dan kita menerima anugerah-Nya, 'kita harus berusaha sebaik-baiknya.' Ini berarti mengasihi Allah di atas segala-galanya. Namun, Allah yang digambarkan kepada Luther adalah sebagai hakim yang menimbang-nimbang jasa orang. Luther merasa terperangkap. Ia tidak bisa mengasihi Allah yang menghukumnya. Namun ia tidak akan diterima sebelum ia mengasihi Allah ... Luther benci kepada Allah karena Ia menghakimi manusia menurut kebenaran, bukan hanya menurut Taurat tetapi juga berdasarkan Injil. (Lane, 2009, p. 132).

Akibat dari siksaan batin ini orang-orang Eropa di zaman Luther dihantui kekuatiran akan 'keselamatan' jiwanya setelah kematian (Karant-Nunn, 2016). Pada masa-masa itu orang mempraktikkan Ars Moriendi (seni mempersiapkan kematian) sehingga di akhir hayat mereka dapat dengan tenang 'kembali kepada Tuhan'. Tetapi terkadang kematian datang dengan tiba-tiba dan dengan cara yang membuat mereka merasakannya sebagai 'hukuman Tuhan' - misalnya kematian karena wabah penyakit. Mereka tentu saja kuatir bahwa kematian yang mendadak semacam demikian dapat mengancam 'nasib kekal' dari jiwa-jiwa mereka karena mereka tidak sempat mempersiapkan 'cara kematian yang baik' dan penyebab kematiannya terkadang dikaitkan dengan dosa-dosa (Swanson, 2010, pp. 357-360). Hal ini tentu menerbitkan teror bagi jiwa orang-orang Abad Pertengahan yang masih melihat bahwa segala sesuatu dalam kehidupan dikendalikan secara langsung oleh Tuhan (Fergusson, 2018, pp. 59-109). Itu sebabnya terobosan teologis yang diutarakan Luther bahwa Allah sesungguhnya mengampuni dan menyelamatkan orang percaya hanya atas dasar kemurahan hati dan melalui iman saja sangat berkesan bagi orang banyak di masa itu.

Terobosan teologi Luther bahwa keselamatan dari murka Tuhan tidaklah bergantung kepada kesempurnaan kepatuhan manusia kepada hukum Taurat ataupun ritual-ritual buatan Gereja, melainkan hanya berdasarkan iman kepada Injil Yesus Kristus saja, telah mengubah jalannya sejarah ke- kristenan untuk selamanya (Berkhof, 2009, pp. 118157). Melalui penekanan bahwa keselamatan hanya diperoleh berdasarkan kemurahan Tuhan dan hanya melalui iman saja, Luther telah memberikan kontribusi yang sangat berharga bagi kekristenan. Luther telah melepaskan gereja dari belenggu 'injil palsu', yang mengatakan bahwa manusia dapat menyelamatkan diri sendiri dari murka Tuhan lewat amal, perbuatan baik, atau ritual-ritual agama - yang di satu sisi dirancang untuk managing the fear of death; tetapi di sisi lain justru mencerminkan kepercayaan berlebihan terhadap kemampuan diri sendiri untuk mengatasi dosa dan barangkali juga penghinaan kepada rahmat yang ditawarkan Tuhan dengan cumacuma di dalam Kristus. Tetapi solusi yang menurut Luther ditemukannya melalui studi surat-surat Paulus ini masih mengandung masalah lain. Solusi yang ditawarkan Luther akan Anfechtung itu mengasumsikan formulasi problem yang, menurut hemat penulis, kelewat anthropo-centric. Luther masih berangkat dari 'kekuatiran-kekuatiran manusia' itu sendiri. Solusi itu masih memahami masalah terbesar umat manusia adalah bahwa mereka 'ada di bawah hukuman'. Apa jadinya jika Luther melihat permasalahannya dari 'sisi Tuhan'? Apa yang salah dengan kejatuhan manusia, jika dilihat dari 'sisi Tuhan' mungkin adalah ini: kehendak Tuhan untuk memancarkan kemuliaan-Nya lewat segala segi ciptaan menjadi terhalang.

Ada penekanan teologis yang lebih kuat kepada 'kedaulatan Allah' dan 'kemuliaan Allah' di dalam tokoh lainnya dalam Reformasi Protestan, yakni John Calvin - walaupun tentu saja ini bukan berarti Luther melihat kemuliaan Allah sebagai sesuatu yang kurang penting (Prins, 1972, pp. 32-44). Dari sisi yang lebih 'teosentris' akan dibahas problema kejatuhan bukan sebagai 'manusia punya masa depan suram' atau 'Allah murka pada manusia' tetapi pada 'kemuliaan Allah terhambat untuk terpancar lewat segenap ciptaan'. Dari pendekatan ini untuk memahami apa yang salah di dalam kejatuhan dengan lebih tepat dan bagaimana penebusan 
dapat dipahami dalam segenap kelimpahan maknanya titik berangkatnya harus diganti. Pemahaman tentang Injil penyelamatan itu janganlah diawali dengan dosa dan kejatuhan, tetapi dengan penciptaan dan kehendak Allah bagi ciptaan itu (Pearcey, 2013, p. 91). Menurut Calvin, tindakan penciptaan tidak dapat dipisahkan dari kehendak Allah dan kemuliaan Allah. Di dalam Treatise on Predestination, John Calvin menulis demikian:

Sebab meskipun Allah tidak tergantung pada seluruh ciptaan-Nya, namun alangkah bodohnya jika kemudian kita menyimpulkan bahwa Ia tidak peduli dengan kemuliaan-Nya ketika Ia menciptakan manusia.... Sebab meskipun Allah tidak kekurangan apapun juga, namun tujuan utama Ia menciptakan manusia adalah agar nama-Nya dipermuliakan di dalam mereka.... Orang-orang fasik diciptakan untuk hari penghukuman. Hal itu tidak akan terjadi kecuali Allah sendiri berkehendak untuk menyatakan kemuliaan-Nya melalui orang-orang tersebut (Wendel, 2010, p. 187).

Jika dikatakan bahwa kemuliaan Allah lah yang paling penting di alam semesta ini, maka permasalahan yang lebih serius bukanlah bahwa orang-orang berdosa akan 'masuk neraka' - tetapi bahwa dosa menghalangi kemuliaan Allah untuk terpancar terang di dalam alam ini secara maksimal. Lebih tepat jika dikatakan bahwa 'manusia ada dan diselamatkan bagi (kemuliaan) Allah' daripada bahwa 'Allah ada bagi manusia' - perlu ada prioritas dalam memahami keduanya. John Calvin memandang segalanya, termasuk penebusan dan kejatuhan, 'dari atas', yaitu dari sisi Allah. Itu berarti bagi Calvin, penebusan dan kejatuhan tak dapat dilepaskan dari penciptaan dan kehendak Allah di dalamnya. Tentu saja penulis tidak hendak mengecilkan pentingnya manusia dan segenap ciptaan bagi Allah sendiri. Yesus sendiri mengatakan bahwa Bapa begitu mengasihi dunia ini sehingga Ia memberikan Anak-Nya yang tunggal itu (Yoh. 3:16) bagi keselamatan manusia. Penekanannya di sini adalah pada raison d'etre dari penyelamatan orang percaya - yang sesungguhnya berakar kepada tujuan manusia dan se- genap alam diciptakan, yakni untuk memancarkan kemuliaan Allah. Jadi manusia bukan diselamatkan supaya tidak binasa belaka, tetapi ia diselamatkan agar kemuliaan Allah dapat terpancar seutuhnya lagi di dalam segenap ciptaan. Selanjutnya untuk menambahkan dukungan argumen dari Alkitab mengenai pemahaman Injil sebagai pemulihan kemuliaan Allah di dalam segenap ciptaan pembahasan akan diteruskan kepada penelitian tentang tafsir bagianbagian Alkitab mengenai pokok kemuliaan Allah, dosa, dan keselamatan.

\section{Tema Kemuliaan TUHAN di dalam Alkitab}

Pada bagian ini penulis akan meninjau thema 'kemuliaan Allah' di dalam Kejadian 1-2, kitab Samuel, kitab Hosea, Mazmur 8, dan Perjanjian Baru melalui kategori metanarasi kristiani, yakni: Penciptaan, kejatuhan, dan penebusan.

\section{Kemuliaan Allah dalam Penciptaan dan Kejatuhan}

Di dalam Perjanjian Lama anda dapat menemukan pemahaman umat Ibrani akan kehendak Allah untuk memenuhi segenap ciptaan dengan kemuliaan-Nya. Sebagai salah satu contoh adalah doxology di dalam Mazmur 8. Pemazmur menulis: "Ya TUHAN, Tuhan kami, betapa mulianya nama-Mu di seluruh bumi!" Setelah menyaksikan 'langit-Mu, buatan jari-Mu' (ay. 4) penulis Mazmur 8 menyatakan keheranannya bahwa Allah yang begitu besar masih saja 'memperhatikan' bahkan 'mengindahkan' manusia (ay. 5). Tidak berhenti di sana, menurut pemazmur, Allah yang begitu besar itu bahkan mengangkat manusia begitu tinggi, mendekati posisi-Nya sendiri sebagai penguasa alam semesta (ay. 7). Manusia telah diangkat 'hampir sama seperti Allah' - dimahkotai dengan 'kemuliaan dan hormat' (ay. 6). Manusia yang diceritakan dibuat oleh Allah dari debu itu telah diberikan kedudukan dan tanggungjawab yang hebat sebagai wakil Tuhan dalam pemerintahan Allah. Tidak heran pemberontakan manusia terhadap Tuhan memiliki dampak seluas ciptaan juga. Akibat kejatuhan jauh lebih luas dan 
radikal daripada sekedar 'jiwa-jiwa berdosa masuk neraka', yang lebih penting daripada itu adalah bahwa kejatuhan membuat kemuliaan Allah pudar dari alam semesta.

Mengenai pemahaman tentang ciptaan sebagai tempat kediaman Allah dan panggilan manusia di dalamnya, Jeff Morrow menulis:

...Eden adalah Ruang Maha Suci di dalam bait Ciptaan Tuhan, implikasinya adalah umat manusia, yang diciptakan di dalam Ruang Suci, seharusnya dipahami sebagai Homo liturgicus. Kita yang hidup di Ruang Maha Suci ini memiliki panggilan untuk menyembah TUHAN di dalam segala pemikiran, kata-kata, dan tindakan (Morrow, 2009).

Contoh yang seperti demikian dapat ditemukan juga di dalam Perjanjian Baru. Dunia ini bukan ada bagi manusia itu sendiri, kata rasul Paulus. Dalam sebuah Doxology yang terkenal dalam surat Roma, dikatakan: "Sebab segala sesuatu itu adalah 'dari Dia', 'oleh Dia', dan 'kepada Dia”" (Rm. 11: 36). Segala sesuatu, termasuk diri manusia ada bagi Allah, bagi kemuliaan-Nya, dan bukan sebaliknya. Visi yang begini agung telah tercemar oleh pemberontakan manusia melawan Allah yang begitu besar dan baik itu. Jadi seharusnya, kerinduan manusia akan penebusan juga mencerminkan kesadaran sebagai umat TUHAN, yakni kerinduan akan pemulihan kemuliaan TUHAN di dalam segenap segi ciptaan. Ratapan manusia di dalam kejatuhan adalah ratapan akan 'hilangnya kemuliaan' itu (ichabod, seperti nama yang diberikan menantu perempuan imam Eli, istri Pinehas, setelah mendengar kabar tentang kematian suaminya, kekalahan Israel dan tertawannya Tabut Perjanjian Allah oleh orang-orang Filistin - 1 Samuel 5: 19-22).

\section{Kemuliaan Allah dalam Penebusan}

Apakah jawaban Allah atas tragedi kemanusiaan ini? Jawaban Allah atas ratapan ini adalah janji-Nya sendiri bahwa Ia akan datang kembali ke Sion, ke Kota Allah. YHWH akan datang kembali ke tengah umat-Nya seusai masa penghukuman me- reka (Wright, 2012, pp. 66-81). Kedatangan Yesus adalah penggenapan dari janji YHWH ini. Yesus Nazaret adalah datangnya Allah Israel ke tengahtengah umat-Nya, berkemah di tengah mereka dan tidak pernah akan pergi lagi.

Motif hadirnya Sang Pencipta dengan segenap kemuliaan-Nya ke tengah ciptaan (walaupun ciptaan telah jatuh dalam dosa) telah dapat dijumpai dalam Perjanjian Lama ketika Musa mendapatkan perintah TUHAN untuk mendirikan Kemah Pertemuan, juga di dalam zaman Salomo, yaitu pada Bait Allah yang permanen; dan kemudian mencapai klimaks naratifnya di dalam klaim Yesus Kristus bahwa Ia akan 'membangun kembali Bait Allah dalam tiga hari'. TUHAN sesungguhnya ingin mendirikan rumah-Nya di bumi, tetapi terhalang oleh dosa - walaupun itu tidak menghalangi TUHAN untuk mendirikan kediaman-Nya di dalam 'spot-spot khusus' seperti di Gunung Sinai, di Ruang Maha Suci di dalam Kemah Pertemuan Musa dan Bait Allah Salomo. Seperti dikatakan Meredith Kline:

Kejatuhan manusia secara radikal mempengaruhi replikasi dari Surga di bumi pada perkembangannya. Sebagai akibat dari melanggar perjanjian, Kemuliaan-Teofani pada saat ini undur dari dunia, walaupun bumi masih berada di bawah kuasa Raja Surga yang berdaulat, tetapi bumi kehilangan kekudusannya. Hanya lewat tindakan penebusan Ruang Maha Kudus itu dapat hadir lagi dalam dunia yang telah jatuh - khususnya di dalam sejarah Israel. Di mana Ruang Suci itu muncul lagi di bumi ini, menekankan sifatnya sebagai tiruan dari archetype Surgawi. Kemah Pertemuan dan Bait Allah, restorasi dari Ruang Suci Eden dengan Tahta Allah yang dijaga Kerub-Kerub dibuat sesuai dengan Ruang Atas dari Bait Allah yang diungkapkan kepada Musa dan Salomo (Kline, 1996).

Jadi permasalahan manusia bukanlah sesempit penderitaan atau prospek 'kematian kekal' akibat hukuman Allah semata - itu semua harus diletakkan di dalam konteks lebih besar, yakni 'lenyapnya kemuliaan' dari dunia ini dan 'kembalinya kemuliaan' ke dalam segenap ciptaan, melalui karya Allah yang datang sebagai Raja Kemuliaan di dalam kedatangan 
Yesus Nazaret di Yerusalem. Nancy Pearcey mengatakan bahwa jika "kita memulai dengan kejatuhan dan bukannya penciptaan, kita tidak akan bisa menjelaskan penebusan - karena sasaran penebusan adalah memulihkan kita kepada status awal kita yang diciptakan" (Pearcey, 2013, p. 91).

Allah menyelamatkan manusia dari murkaNya bagi suatu tujuan di luar 'keluputan dari murka' itu sendiri. Bahkan, jikalau 'keselamatan' dipandang secara lebih tepat, yaitu sebagai suatu 'pembebasan dari belenggu dosa', atau sebagai 'pemulihan dari penyakit dosa yang mematikan' - tetap saja ada suatu alasan di luar keselamatan manusia itu sendiri dari murka Allah, yang menjadi tujuan Allah untuk menyelamatkan. Dallas Willard mengatakan bahwa menyempitkan Injil menjadi 'Injil manajemen dosa pribadi' semacam ini akan menghasilkan polarisasi: orang-orang Kristen tertentu jadi buta akan urusan 'dosa struktural' dalam masyarakat - sedang di sisi lainnya, orang-orang Kristen yang melek akan urusan dosa struktural cenderung kurang serius dalam urusan kekudusan hidup pribadi:

Ketika kita memeriksa spektrum yang begitu luas dari proklamasi dan praktik kekristenan, kita melihat di dalam teologia sayap kanan, satu-satunya hal yang dianggap esensial adalah pengampunan dosa-dosa individual. Sedangkan pada sayap kiri penekanannya adalah pada bagaimana melenyapkan dosa-dosa sosial atau struktural. Akibatnya, Injil pada masa kini hanya dipahami sebagai 'Injil manajemen dosa'. Transformasi kehidupan dan karakter tidaklah memiliki bagian di dalam berita penebusan. Realitas hidup manusia dari satu momen ke momen dalam segala kedalamannya tidaklah menjadi arena dari iman dan kehidupan kekal. Di sayap kanan, menjadi Kristen sekedar berarti pengampunan dosa (ingat stiker mobil itu?) Di sayap kiri, anda barulah sungguh-sungguh Kristen jika anda memiliki komitmen untuk melenyapkan kejahatan-kejahatan sosial (Willard, 1997, pp. 40-42).

Sesungguhnya kedua penekanan dari Injil ini, walaupun memang patut dibedakan, tetapi tidak dapat saling dipisahkan: pengudusan pribadi dan pengudusan dunia ini - karena Tuhan menghendaki untuk berdiam di sini, di bumi, bersama dengan umat-Nya yang kudus.

Penulis surat Efesus, misalnya, mengatakan bahwa Allah menyelamatkan orang percaya untuk 'menjadi kudus dan tak bercacat' di hadapan-Nya (Ef. 1: 4). Menjadi 'kudus' di sini tak dapat dilepaskan dari konteks pengharapan Israel, yang memahami 'kudus' sebagai 'dikhususkan bagi Allah' (misalnya tentang ramuan ukupan yang dikuduskan bagi Allah di dalam Keluaran 30:37-38). Di dalam Efesus $1: 14$, penulis surat itu menyebutkan tujuan 'penebusan' yang Allah kerjakan di dalam Kristus yaitu untuk 'menjadikan kita milik Allah untuk memuji kemuliaan-Nya'. Dengan kata lain, luput dari murka Allah hanyalah satu bagian kecil dari keseluruhan penghayatan spiritualitas para penulis Alkitab seperti penulis Kejadian pasal 1, Mazmur 8, dan surat Efesus tentang 'keselamatan' yang dimiliki di dalam Kristus Yesus. Diselamatkan itu bukan melulu diselamatkan dari hukuman. Di dalam Kristus orang percaya diloloskan dari murka Allah untuk suatu tujuan lain. Ada tujuan yang lebih utama dari keselamatan yang dikerjakan Kristus selain meluputkan orang percaya dari neraka, yakni untuk menjadikan mereka 'milik Allah bagi kemuliaan-Nya' dan itu adalah sebagian dari proyek besar pemulihan kemuliaan Allah dalam segenap ciptaan - dalam tatanan masyarakat ini adalah pengudusan masyarakat dari penyakit dosa strukturalnya (lihat Roma 8:19-22).

\section{Injil sebagai Kabar tentang Kembalinya Kemuliaan Allah ke dalam Ciptaan}

Apakah implikasi dari memandang Kabar Baik Injil sebagai 'keluputan saya dari murka Allah' dengan memandangnya secara lebih utuh sebagai 'pemulihan ciptaan' yang dimulai dengan 'kembalinya Allah kepada umat-Nya' dan menjadikan manusia kembali menjadi 'anak-anak Allah' - dan dengan demikian meletakkan motif 'pengampunan dosa' di dalam kerangka lebih luas? Jika Injil Yesus Kristus yang dipahami secara lebih utuh begini akan menghindarkan ketegangan antara 'kesalehan pri- 
badi' vs. 'tanggung jawab sosial' atau dalam beberapa kalangan disebut dengan istilah 'mandat Injil' vs. 'mandat budaya' (Colson, 1999, p. xii). Jikalau Injil Yesus dipandang sebagai datangnya Allah $\mathrm{Ab}$ raham sebagai Raja kembali ke dalam ciptaan yang adalah rumah-Nya ini, maka kiat tidak perlu terperosok kepada spiritualitas 'escapist' atau 'extramundane' yang merindukan untuk 'lepas dari dunia ini' ke sebuah dunia yang 'lebih baik' ('surga'?) yang ada entah di mana itu. Kemungkinan spiritualitas seperti ini lebih mencerminkan pengaruh $\mathrm{Yu}$ nani-Romawi (mungkin Plato dan Plotinus) daripada pengaruh Ibrani di dalam Kekristenan Barat pada Abad Pertengahan, yang mana pengaruhnya masih dapat ditemukan dialam banyak kalangan kekristenan dewasa ini. Plato, yang banyak mempengaruhi para teolog yang membandingkan jiwa manusia yang terkurung dalam tubuh seumpama kerang di dalam cangkangnya (Plato, 2009). Umat Tuhan tentu tidak seharusnya melihat tubuh material, Pemberian Allah secara sedemikian negatif. Keselamatan seharusnya tidak dihayati sebagai janji kelepasan dari 'penjara tubuh'tetapi menantikan kapankah TUHAN akan datang kembali ke bumi sebagai Raja Kemuliaan yang akan membebaskan segenap mahluk dari penindasan dosa (Largen, 2006, pp. 263-274).

Mana-masa penantian akan datangnya pemerintahan Allah Israel itu telah berakhir dua ribu tahun yang lalu di dalam kedatangan Raja Yesus ke Yerusalem, walaupun ternyata kembalinya kemuliaan dan keadilan itu terjadi tidak sekaligus, masih ada penahanan dan eksekusi yang sewenang-wenang dialami oleh Yohanes Pembaptis, dan kemudian juga dialami oleh Yesus Nazaret dan murid-murid-Nya (Mrk. 1: 14-15, Yoh. 15: 20, Kis. 8: 1-3). Dengan kata lain, umat TUHAN sepatutnya tidak menghayati spiritualitas yang eskapis melainkan adventis, Allah akan datang menjumpai milik-Nya di bumi, bukan manusia yang akan pergi meninggalkan dunia ini dengan segala kekacauannya (Middleton, 2006). Implikasi Injil kepada keterlibatan sosial budaya orang-orang percaya sangatlah besar. Tanggung ja- wab manusia kepada dunia ini bukanlah sebatas tanggung jawab anak kos pada kamar kontrakannya, tetapi tanggungjawab manajer aset yang diserahi segala harta milik Tuan Besar selama ia bepergian (bnd. Matius 21: 33-34). Kabar baik Injil bukanlah bahwa Tuhan akan menyelamatkan manusia dengan cara membawa orang percaya pergi dari dunia ciptaan ke tempat yang lain, barangkali seperti di dalam dongeng Grimm bersaudara di mana seorang Ksatria Berkuda Putih menyelamatkan Rapunzel dari menara tempat ia ditawan. Gambaran Keselamatan yang diberikan di dalam Alkitab tidaklah sesuai dengan Soteriologi Sekoci Penyelamat di mana 'Kapal Titanic'yaitu 'dunia ini' sedang tenggelam dan orang percaya diselamatkan oleh Yesus untuk pergi meninggalkan dunia yang sedang dilanda kehancuran itu. Salah satu contoh paling terkenal dari ajaran yang mengusung model Sekoci Penyelamat ini adalah dari D. L. Moody (1837-1899):

Moody ...berbicara dengan bahasa pre-millenialisme ketika ia berkhotbah tentang bumi sebagai 'kapal karam' dan Tuhan memberinya sekoci penyelamat dan sebuah mandat: "Moody, selamatkan sebanyak yang engkau mampu (Fanning, 2009).

Di dalam Alkitab itu sendiri ada gambaran yang sangat berbeda, misalnya dalam Yesaya 35: 1-10 ada lukisan tentang segenap ciptaan yang kembali bersukacita menyongsong kembalinya kemuliaan ke dalam segenap alam (lih. Yesaya 35:1-10).

Padang gurun dan padang kering akan bergirang, padang belantara akan bersorak-sorak dan berbunga; seperti bunga mawar ia akan berbunga lebat, akan bersorak-sorak, ya bersorak-sorak dan bersorak-sorai. Kemuliaan Libanon akan diberikan kepadanya, semarak Karmel dan Saron; mereka itu akan melihat kemuliaan TUHAN, semarak Allah kita.

Orang-orang yang percaya dan menyambut Kabar Baik Yesus mengenai pemulihan kemuliaan segenap ciptaan tentu saja tidak akan tinggal diam melihat 'dosa-dosa struktural' seperti: ketidakadilan sosial, kejatuhan dalam pola-pola relasi antar suku, antar jenis kelamin, bahkan antar-spesies (misalnya keke- 
jaman kepada hewan atau pengrusakan lingkungan). Orang-orang percaya seharusnya meratap saat melihat eksploitasi atas nama kemajuan ekonomi dari para 'pemain besar' kepada para 'pemain kecil', eksploitasi para lelaki kepada perempuan, manipulasi para perempuan kepada kaum lelaki, kecurigaan yang terpelihara antar suku, antar golongan, antar ideologi politik, antar jenis profesi - sebab bukan kemuliaan TUHAN yang terpancar dari realitasrealitas demikian.

Datangnya Kerajaan Allah di dalam Yesus menerbitkan pengharapan yang tidak mengecewakan bahwa manusia dapat turut serta dalam peperangan melawan 'dunia jahat ini' dan cara-caranya yang telah merampok manusia dari kemanusiaannya, merusak keindahan dan kepenuhan makna dari kehidupan ini. Kehadiran orang percaya adalah cara TUHAN di zaman ini untuk menjawab jeritan mereka yang tertindas, air mata mereka yang terinjak-injak, dan darah orang-orang tak bersalah yang tertumpah didalam cara-cara dunia ini berbaris menuju 'kemuliaan' semu yang sia-sia. Penulis berpendapat hal inilah yang seringkali terlupakan dari Injil dan penghayatan tentang keselamatan.

\section{KESIMPULAN}

Penekanan yang reduktif kepada Injil keselamatan jiwa dari murka Allah (Injil manajemen dosa) telah membuat para penganutnya gagal melihat relevansi Injil dengan dosa struktural, panggilan politis orang Kristen, dan keadilan sosial. Hal ini dapat melahirkan ketegangan antara dua kubu Kristen, di sisi 'kanan' adalah mereka yang menghidupi Injil sebagai 'obat' bagi dosa-dosa pribadi tanpa melihat relevansinya dengan ketidakadilan struktural; sedangkan di sisi 'kiri' orang-orang Kristen yang lain peka terhadap 'apa yang salah dan jahat' di dalam

\section{DAFTAR RUJUKAN}

Berkhof, Hendrikus dan I. H. Enklaar. (2009). Sejarah Gereja. Jakarta: BPK. struktur sosial tetapi kurang mengindahkan tuntutan kekudusan moral pribadi dan jalan keluarnya di dalam Kristus. Jika orang-orang percaya menyadari bahwa keselamatan yang dibukakan pintunya oleh Injil Yesus Kristus bukan sekedar menjawab ketakutan mereka akan hukuman Tuhan dan memahami bahwa keselamatan itu berarti kembalinya berkat-berkat dan kemuliaan Tuhan ke dalam segala sendi ciptaan, maka mereka akan melihat relevansi dari permasalahan-permasalahan keadilan sosial, 'dosa-dosa privat', krisis di dalam relasi-relasi keluarga, prasangka-prasangka dan perpecahan antar golongan dan etnis dengan kabar baik dari Injil. Dalam artikel ini penulis telah menunjukkan bagaimana memahami Injil penebusan 'dari atas' - yakni dari sisi 'kehendak Allah atas ciptaan', 'kemuliaan Tuhan', dan 'kekudusan Tuhan, manusia, dan masyarakat' akan menghindarkan warga gereja dari polarisasi yang bersumber pada penghayatan Injil yang tidak utuh. Penulis mengusulkan pemahaman tentang penebusan bukan sebagai jawaban atas dosa belaka, melainkan sebagai bagian dari narasi besar Alkitab, yakni: Penciptaan, Kejatuhan, Penebusan, dan Konsumasi segenap ciptaan. Dalam pandangan ini pengampunan dosa pribadi diletakkan sebagai bagian dari pengudusan seluruh hidup, dan pengudusan seluruh hidup sebagai bagian dari penebusan segenap ciptaan, dan penebusan segenap ciptaan sebagai bagian dari kembalinya kemuliaan TUHAN memenuhi segenap ciptaan dalam segala aspeknya ketika Ia berdiam di tengah umat-Nya dalam segala kekudusan dan kemuliaan. Menurut penilaian penulis dengan pemahaman yang seperti inilah relevansi Injil dapat dengan jernih terlihat, baik dalam pengudusan kehidupan pribadi maupun dalam proses transformasi sosial.

Brown, Peter. (1997). Authority and the Sacred: Aspects of the Christianisation of the Roman World. NY: Cambridge Univ. Press. 
Colson, Charles dan Nancy Pearcey. (1999). How Now Shall We Live? Carol Stream, Illinois: Tyndale House Publishing.

Fanning, Don. (2009). "Eschatology and Missions"Themes of Theology that Impacts Missions. Liberty University Journal.

Gilbert, Greg. (2010). What is the Gospel. Wheaton, Illinois: Crossway Books.

Grimm, Wilhelm dan Jacob Grimm. Rapunzel. Berbagai versi kisah ini dapat dijumpai dari berbagai sumber, misalnya: https://web.archive.org/web/2012012221181 4/http://german.berkeley.edu/poetry/rapunze 1.php diakses pada tanggal 24 April 2019.

Fergusson, D. (2018). The Latin Default Setting. In The Providence of God: A Polyphonic Approach (Current Issues in Theology, pp. 59-109). Cambridge: Cambridge University Press. doi:10.1017/9781316822562.003

Karant-Nunn, S. (2016). "Martin Luther on Death and Dying". Oxford Research Encyclopedia of Religion.Ed. Retrieved 14 May. 2019, from

https://oxfordre.com/religion/view/10.1093/ acrefore/9780199340378.001.0001/acrefore9780199340378-e-341.

Kline, G. Meredith. (1996). "Space and Time in the Genesis Cosmogony".Perspectives on Science and Christian Faith, (48): 2-15. California: The American Scientific Affiliation.Dapat dibaca dalam laman https://meredithkline.com/klinesworks/articles-and-essays/space-and-timein-the-genesis-cosmogony/ diakses pada 7 Mei 2019.

Kline, Meredith. (1958). "Because It Had Not Rained" The Westminster Theological Journal 20.

Lane, Anthony. (2009). Runtut Pijar. Jakarta: BPK.

Largen, K. J. (2006). "Liberation, Salvation, Enlightenment: An Exercise in Comparative
Soteriology”. Dialog, (45): 263-274. doi:10.1111/j.1540-6385.2006.00276.x

Littlejohn, W. Bradford. (2017). "Addicted to Novelty: The Vice of Curiosity in a Digital Age". Journal of the Society of Christian Ethics, 37 (1): 179-196. DOI: 10.1353/sce.2017.0000

Marshall, Peter. (2010). "Leaving the World". Peter Matheson (G. ed.) dan Denis R. Janz (Ed.). Reformation Christianity: A People's History of Christianity. MN: Augsburg Fortress Press.

McKnight, Scot. (2016). The King Jesus Gospel. Grand Rapids, MI: Zondervan.

Middleton, J. Richard. 2006. "A New Heaven and a New Earth: The Case for a Holistic Reading of the Biblical Story of Redemption". Journal for Christian Theological Research 11 (7): 73-97.

Morrow, Jeff. (2009). "Creation as Temple-Building and Work as Liturgy in Genesis 1-3". The Journal of OCABS, Vol 2 (1).http://www.ocabs.org/journal/index.php/j ocabs/article/viewFile/43/18 diakses pada 7 mei 2019.

Ngabalin, M. (2017). "Teologi Pembebasan Menrut Gustavo Gutierrez dan Implikasinya bagi Persoalan Kemiskinan". KENOSIS: Jurnal Kajian Teologi, 3 (2): 129-147. Retrieved from http://ejournal.iaknambon.ac.id/index.php/KNS/arti cle/view/10/47

Pearcey, Nancy. (2013). Kebenaran Total: Membebaskan Kekristenan dari Tawanan Budaya. Jakarta: Penerbit Momentum.

Plato. (2009). "Faedo". Dalam Ioanes Rakhmat (Ed.), Sokrates dalam Tetralogi Plato: Sebuah Pengantar dan Terjemahan Teks. Terjemahan oleh Ioanes Rakhmat. 2009. Jakarta: Gramedia.

Prins, R. (1972). The Image of God in Adam and the Restoration of Man in Jesus Christ: A Study 
in Calvin. Scottish Journal of Theology, 25(1): 32-44.

doi:10.1017/S0036930600027642

Piper, John. (2010). Let the Nations be Glad: The Supremacy of God in Mission. Grand Rapids, Michigan:Baker Academic.

Singgih, E. G. (2012). "Some Notes on Corruption in Indonesia: A Cultural-Religious Perspective".Exchange , (41): 318-319.

Swanson, R. N. (2010). "The Burdens of Purgatory”. Dalam Daniel Bornstein (G. ed.) dan Denis R. Janz (Ed.), Medieval Christianity. MN: Augsburg Fortress Press.
Wendel, Francois. (2010). Calvin: Asal-usul dan Perkembangan Pemikiran Religiusnya, Jakarta: Penerbit Momentum.

Willard, Dallas. (1997). The Divine Conspiracy. New York: Harper Collins.

Wright, Christopher J. H. (2007). Salvation belongs to Our God: Celebrating Bible's Central Story. Downers Grove, Illinois: IVP.

Wright, N. T. (2012). How God Became King: The Forgotten Story of the Gospels. New York: Harper One. 